\title{
Is FDI Integrating the World Economy?
}

\author{
Ashoka Mody* \\ January 14, 2004
}

Forthcoming in World Economy

\footnotetext{
* Research Department, International Monetary Fund, Washington D.C. This paper was presented at the XIII World Congress of the International Economic Association in Lisbon, Portugal, in September 2002. The views presented here are those of the author and should not be attributed to the IMF. I am grateful to Robert Solow for asking me to write the paper, to Mary Amiti, Alex Lehmann, Prakash Loungani, and two referees for their helpful comments, and to Adrian de la Garza and Young Kim for research assistance.
} 


\begin{abstract}
The spectacular growth and diverse forms of FDI during the past two decades represented an important force generating greater economic integration. Capital flows through FDI increased substantially in relation to global productive capacity, the growing importance of the mergers and acquisitions component of FDI put domestic corporate laggards on notice, and the spread of FDI to non-tradable service sectors generated the possibility that these traditionally low productivity sectors would be brought closer to the standards of international efficiency. Yet, FDI did not perform an integrating role in a more fundamental sense. There is little evidence that FDI served to speed up income convergence across countries. This was the case for two reasons. First, FDI flows remained highly concentrated. Second, the benefits from FDI appear to have accrued principally where conditions were already conducive to investment and growth. Hence, though cross-country disciplines through bilateral, regional, and multilateral efforts are important in reducing the distortions that lead to misallocation of capital, but ultimately domestic efforts to raise absorptive capacity will be critical. Efforts to increase labor mobility, as foreseen, for example, under GATS, could have a significant effect in raising the benefits from FDI as the more mobile labor serves to bridge the cultural, institutional, and contractual differences across nations.
\end{abstract}




\section{Introduction}

At first pass, the answer to the question posed in the title of this paper is a resounding "yes." Foreign direct investment — or FDI — has spread rapidly through the world economy in the past two decades. More countries and more sectors have come become part of the international FDI network. The high level and diverse forms of FDI represent an important force generating greater global economic integration.

However, this is not a complete, nor even the right, conclusion since it is necessary to define the term "integration" more precisely. Markets for goods and assets are regarded as integrated when their prices across nations converge. More trade may be symptomatic of global links but price convergence is the true evidence of integration. When considering FDI, however, no easy market price is identifiable. The presumption is that the flow of FDI brings closer together the returns to capital and labor across nations. A test, therefore, of global integration through FDI is whether it acts to facilitate the process of per capita income convergence across the nations.

There is good reason to put FDI to this somewhat severe test. FDI is thrice blessed. It brings scarce capital where capital is needed and productive. It stimulates the domestic market for corporate control and hence serves to discipline managers. It is the bearer of knowledge to enhance productivity, potentially to the levels of international best practice.

There is reason also to believe that FDI could have acted in the past two decades, through each of its three attributes, to foster income convergence. The spectacular growth in FDI raised capital flows in relation to global productive capacity. The increasing importance of the mergers and acquisitions component of FDI put corporate laggards on notice. And the spread of FDI to 
non-tradable service sectors generated the possibility that these sectors with traditionally low productivity would be brought closer to the standards of international efficiency.

The answer to the question in the paper's title flips if integration is assessed in terms of income convergence. That promise of FDI is yet to be fulfilled. There is little evidence that FDI served to speed up convergence despite the important trends in its levels and composition. This was so for two reasons. First, FDI flows remained highly concentrated. Second, the benefits from FDI appear to have accrued principally where conditions were already conducive to investment and growth. FDI can, at least temporarily, draw a country's resources from domestic entrepreneurs who are unprepared to deal with the competition.

The policy and regulatory agenda at the domestic and international levels has focused on the need to further reduce barriers to foreign investment without creating undesirable tax competition among nations. By necessity, progress has been incremental and, even if the current efforts are successful, there is no reason to believe that the role of FDI will change significantly. I suggest, somewhat speculatively, that FDI that is associated with greater labor mobility could prove to be more of an integrating force.

This paper is a selective survey of the literature, with an attempt to highlight results from recent and ongoing research. Inevitably, the selection of research reported is biased towards my own interests and analyses. The rest of this paper is organized around three objectives: first, to provide an overview of the trends in the levels and composition of FDI flows; second, to consider the analytical basis for the high concentration of FDI and the mechanisms through which FDI has an impact on domestic economies; and third, to describe the policy and regulatory issues faced at the level of the host country and in bilateral, regional, and multilateral forums. 


\section{The Spread of FDI}

Ostensibly, FDI has been an integrating force in several ways. The first, and most obvious, indicator is the rapid - indeed, explosive - growth in FDI. Figure 1 shows these global trends. From about $\$ 55$ billion in the early 1980s, annual worldwide FDI rose to just over $\$ 200$ billion in 1990 and then rose dramatically over six-fold to almost $\$ 1.4$ trillion in 2000 . While much of increase represented a recirculation of capital within developed countries, developing countries also benefited from the huge expansion during this period. In the 1990s, FDI flows to developing countries rose from just under $\$ 40$ billion in 1990 to over $\$ 240$ billion in 2000, again a more than six-fold increase.

The large absolute rise in FDI also implied that FDI grew faster than world production and trade, especially during the 1990s. Figure 2 shows that the ratio of FDI to GDP rose steadily for developing countries from less than a quarter percent in 1970 to under 1 percent in 1990 and then to over 4 percent in 2000. This was a major transformation reflecting both the push of investors seeking high return opportunities and the pull from developing countries seeking needed investment and technology.

A second feature of FDI flows was the importance of international mergers and acquisitions. FDI may be in the form of "greenfield" projects (those projects where new investments are undertaken) and mergers and acquisitions (which entail the acquisition by foreign investors of ongoing domestic operations). Mergers and acquisitions were always important in developed country transactions but their significance grew also for developing economies following the crises of the mid-1990s, as Figure 1 shows. In turn, these mergers and acquisitions reflected privatization of public sector assets in a number of developing countries in 
Latin America, and the international purchase of distressed banking and corporate assets in several Asian economies in the wake of the crisis triggered in July 1997.

A third important characteristic of FDI flows in the past decade was a massive shift into the services sector. Traditionally, FDI was directed to the development of natural resources and to manufacturing enterprises. In particular, during the 1980s, FDI flows increased to take advantage of lower costs of product assembly in developing economies, typically for exports to world markets. However, in the 1990s, increasingly larger shares of FDI went to service production and delivery — into such sectors as finance and telecommunications and more recently into wholesaling and retailing. The high level of mergers and acquisitions reported above and increased entry of foreign investors in service sectors were related. Figure 3 shows the transformation over time in the sectoral composition of mergers and acquisitions from a gradually declining share of the primary and manufacturing sectors and a rise of business services, finance, and communication; the trend applies to all of FDI, destined both for developed and developing countries.

Thus, at least in these three respects FDI flows acted to integrate developing countries into the world economy. There was substantially more FDI, it appeared increasingly in the form of mergers and acquisitions, and in a new range of service sectors. The reasons to celebrate these trends were clear. First, FDI brought in capital to capital-scarce economies. Second, in the form of mergers and acquisitions, it played an increasingly important role in generating competitive discipline in the domestic market for corporate assets. And, finally, by expanding its reach into service sectors, FDI promised to bring productivity gains to those non-tradable sectors where productivity growth has traditionally lagged and where the gaps between developed country best practice and developing country efficiency levels are large. 
Before turning to the assessment of the benefits that FDI did bring, it is useful to consider briefly what may have caused the huge upsurge in FDI and whether trends witnessed in the past two decades are likely to continue. We can presume that the promise of high returns drove FDI, but was that promise based on real prospects or did FDI follow the bubble in asset markets? This question that has not been carefully analyzed and one can only speculate. An important observation in this context is the massive flow of FDI that occurred into the United States. To steal a phrase from Ross Perot, the erstwhile U.S. Presidential candidate, if there was "a giant sucking sound," it was into the U.S. not away from it, as he had feared. Much of this investment went into the booming U.S. telecommunications and finance sectors. It is likely that the same euphoria was influential in driving FDI to other countries. With disappointment in the returns to that investment, it is not surprising that FDI has slowed down. While I have described in some detail the run up in FDI in the 1980s and 1990s, Figures 1 and 2 conspicuously point to a sharp decline thereafter. From a high of about $\$ 1.3$ trillion, worldwide FDI was down to $\$ 820$ billion in 2001 and to $\$ 650$ billion in 2002. For developing countries also, FDI flows fell sharply in 2001 and 2002.

While a formal forecasting exercise is not appropriate in the context of this paper, consider some sources of future FDI growth—some suggesting an optimistic outlook, others less so. First, an UNCTAD survey of multinationals suggests that despite the disruption following from the events of September $11^{\text {th }}$ FDI trends will not be affected on that account (UNCTAD 2002). Only a very small fraction of firms reported a postponement of their plans. This is consistent with the view that FDI investors take a long-term view and, hence, FDI flows tend to be more stable than other forms of foreign capital flows (see, for example, Lucio Sarno and Mark Taylor 1999). Second, with declining scope for privatization, will FDI to developing countries be 
especially hurt? The answer depends on whether the decline in mergers and acquisitions activity will be offset by new investment. Recently acquired firms may benefit from continued foreign funding of new investment. Both econometric and survey findings, in this respect, are encouraging. Cesare Calderon, Norman Loayza, and Luis Serven (2002) find that mergers and acquisitions are followed by new "greenfield" investments. The UNCTAD survey is consistent with these findings and reports, for example, that Brazilian firms acquired by foreign companies do expect new foreign funding. Finally, a more potent force on FDI prospects is likely to be the slowdown in world growth. As discussed below, econometric results strongly suggest that high growth rates attract foreign investment. FDI's decline in 2001 and 2002 was, in large measure, a consequence of the worldwide deceleration in growth (Rui Albuquerque, Norman Loayza, and Luis Serven 2002 conclude that "world factors" rather than domestic factors drove the volume of FDI in the 1990s). If world economic growth remains subdued, then FDI flows are also likely to remain flat.

\section{Why FDI Flows Remain Concentrated}

Robert Lucas (1990) laid out the challenge in his famous paper: “Why Doesn’t Capital Flow from Rich to Poor Countries?" Poor countries, with scarce capital, should provide much higher marginal returns to capital than rich countries. That, in turn, should result in virtually all new investment occurring in the poor developing nations. Of course, the reality is not even close to that prediction. Figure 4 shows that over 80 percent of the world's population resides in developing nations and, at reported exchange rates, they produce just over 20 percent of the world's GDP (the share of developing country GDP is higher when allowance is made for differences in purchasing power). By these benchmarks, developing country share of world FDI 
has been modest. In the mid-1990s, when flows to developing countries were most buoyant, the developing country share reached around one-third, but for the most part of the past three decades, the share has averaged around one-fifth.

Further, within developing countries, the richer pull in the bulk of the FDI. Figure 5 shows that the middle-income countries had a significantly higher FDI/GDP ratio than lowincome countries and that this gap grew over the 1990s. ${ }^{1}$ Moreover, the 10 largest recipients of FDI - accounting for 80 percent of developing country FDI in the 1990s - all fell in the middleincome group and their FDI/GDP ratio was even higher. ${ }^{2}$ The top 3 recipients, Brazil, China and Mexico (with about a third of developing country GDP), absorbed just over half of developing country FDI. Moreover, as the lower panel of Figure 5 shows, during this period, middle-income countries grew faster than low-income countries and the top 10 grew even faster, suggesting a synergistic relationship between growth and FDI. Further, the positive relationship between the FDI-GDP ratio appears even within each of these country groups, though to varying degrees (Figure 6). Thus, higher level of development (reflecting institutional maturity) and higher country growth rate explain much of the cross-country allocation of FDI in the 1990s.

Finally, Michael Clemens and Jeffrey Williamson (2000) find that the "Lucas Paradox" was also operative in the late $19^{\text {th }}$ and early $20^{\text {th }}$ century with respect to British export of capital. They define such a paradox to exist when a host country's GDP per capita exercises a "powerful

\footnotetext{
${ }^{1}$ The analysis in Figures 5 and 6 excludes small countries (those with population less than 1 million) and transition countries (which had limited data for the 1990s and volatile behavior of both investment and output). See the Appendix for the list of countries in various country groups.

${ }^{2}$ In order of FDI received, these included: China, Brazil, Mexico, Argentina, Malaysia, Poland, Chile, Thailand, Venezuela, and Colombia.
} 
positive affect" on the share of international capital flows received. In analyzing the reasons for the Lucas paradox, then and now, Clemens and Williamson (2000) propose that two sets of factors are at work. First, despite its scarcity, capital may be unproductive in poorer countries because of the absence of needed complementary inputs. Second, capital markets may fail for a variety of reasons to allocate capital efficiently. They conclude that market failure was unimportant and that the dominant reason for the Lucas paradox was differences in country fundamentals that made capital more productive in rich countries. The fundamentals they find to be of importance are: the fraction of children enrolled in primary schools, share of primary products in exports, immigration, and population growth. To represent possible misallocation of capital, Clemens and Williamson (2000) considered colonial status and adherence or otherwise to the gold standard, a proxy for commitment to macroeconomic discipline. Neither proved statistically significant.

Similar analyses for the more recent decades also find evidence for the importance of operating conditions that reduce capital productivity but, in addition, scale economies and informational gaps are found to play a significant role. David Wheeler and I found in an early paper that domestic country attributes mattered for U.S. foreign investors (Wheeler and Mody 1992). Of particular significance was infrastructure availability. A subsequent paper with Krishna Srinivasan also considered Japanese foreign investment decisions and found further evidence for the importance of infrastructure and human capital (Mody and Srinivasan 1998). ${ }^{3}$ In addition, higher levels of country risk deterred foreign investors. Significantly also, the past stock of foreign investment was extremely important in explaining new inflows of FDI.

\footnotetext{
${ }^{3}$ In Mody, Susmita Dasgupta, and Sarbajit Sinha (1999) we found that in their investment decisions, Japanese investors were more concerned about labor quality than about lower wages.
} 
The finding that past stock of foreign investment matters in determining new flows is subject to various interpretations, including omitted country variables. In Wheeler and Mody (1992) and Mody and Srinivasan (1998), we proposed that the presence of agglomeration economies attracted foreign investors but offered no direct evidence to support that conjecture. Using a survey of Japanese investors, Yuko Kinoshita and I focused on informational gaps and found evidence consistent with a significant value attached to private information (Kinoshita and Mody 2001). Investors who already had a presence in a particular host country were likely to have more ambitious investment plans in that country rather than in alternative locations. At the same time, when contemplating investment in a country that was "new" to them, investors were strongly influenced by the behavior of other investors, i.e., their likelihood of investing in the new country increased considerably if they perceived that others found it a desirable location. In other words, the evidence suggested a "herd-like" movement over and above that explained by country and industry characteristics.

More recently, Prakash Loungani, Assaf Razin and I have approached this question from a different perspective (Loungani, Mody, and Razin 2002). In so-called "gravity" models of bilateral investment, distance between the two countries appears with a large and negative sign. However, economic theory does not necessarily predict that greater distance between two countries should reduce the FDI that flows between them. Indeed, the opposite is predicted for "horizontal" foreign investment, which is investment undertaken as a substitute for trade when distance creates high transportation costs. We test the possibility that physical distance between countries proxies, among other things, for "informational distance," which we represent by bilateral telecommunications capability. Better information capability does stimulate more bilateral investment. Moreover, when such an informational variable is introduced into the 
regression, the coefficient of physical distance actually becomes positive for developed countries, suggesting that horizontal investment may be the dominant motive for FDI flows among developed countries. For developing countries, the coefficient on physical distance remains negative and significant, but better informational capacity reduces the disadvantage of physical distance.

Finally, econometric evidence typically supports the positive relationship between growth and FDI suggested in Figures 5 and 6. Robert Lipsey and Zadia Feliciano (2002) consider the factors that attract foreign investment into the United States. They find that high rates of U.S. growth lead to both acquisitions and new establishments. Firms are also acquired when they suffer from low profitability and are faced with high costs of capital, lending support to the role that foreign investors play in the market for corporate control. Foreign investors who establish new firms come from countries that have a comparative advantage in that activity.

To summarize, the Lucas paradox-i.e., the high correlation between per capita incomes and FDI flows - stems from three, possibly related, causes. High-income countries have better fundamentals, such as infrastructure and human capital. Moreover, poorer countries are also associated with higher measures of corruption: Beata Smarzynska and Shang-Jin Wei (2002) find that corruption lowers FDI, especially the FDI with high intellectual property content. At the same time, agglomeration economies and informational gaps have the effect of creating clusters of investors in more favorable operating conditions. And, finally, growth and FDI can have a mutually reinforcing relationship. The suggestion is that FDI is largely reactive to prevailing conditions and is not principally a source of entrepreneurship and creativity but rather is able to exploit favorable host country conditions. In the next section, I examine more directly the conditions under which FDI benefits the host economy. 


\section{Has FDI Helped Income Convergence?}

FDI can benefit the host economy by boosting domestic investment and by raising productivity. The evidence suggests that investment effect applies in a broad range of conditions, though over time a dollar of FDI has been associated with less than a dollar of investment. Productivity benefits are more controversial. While anecdotal evidence of knowledge transfer through training and turnover of employees is often cited, the econometric evidence — using either firm-level data or aggregate data—offers much weaker support for productivity benefits. To the extent such benefits exist, they accrue where economic conditions are already favorable: FDI thus operates to support and enhance an existing growth dynamic.

\section{FDI and Domestic Investment}

Barry Bosworth and Susan Collins (1999) conducted an extensive analysis of the effect of foreign capital flows on domestic investment and found that a dollar of FDI to developing economies translated into a dollar of domestic investment; in contrast, bank loans and bond funds were less effective in generating investment in the host economy. This was an important finding but one that was not surprising. Most FDI up until the end of their sample period, i.e., 1995, was in the form of greenfield projects, which, by definition, involve new establishments. In contrast, bank loans and bond issuance may not be related to new investment. Extending their analysis in several ways, Antu Murshid and I find that marginal impact of FDI flows declined in the 1990s, especially in the second half of the decade (Murshid and Mody 2002). This may have resulted from the larger share of mergers and acquisitions in FDI flows. 


\section{FDI and Productivity Spillovers}

While the problem of attributing causation to foreign inflows is hard enough when analyzing short-term movements in domestic investment, it is especially difficult in considering the impact on productivity. Productivity growth is inherently a more medium-term phenomenon and hence, over that period, is likely to influence the level of foreign inflows. Research results remain ambiguous and, if anything, an increasing number of results point to limited productivity gains from FDI. Richard Caves (1999) has suggested that the ambiguity in the research findings with respect to the existence of productivity spillovers from foreign investment could reflect differences in host country absorptive capacity.

A number of possible mechanisms exist through which foreign investment can generate spillovers, i.e., increase or decrease the productivity of domestic firms. Consider, first, the socalled "horizontal" spillovers. In the empirical literature, these have been defined as the productivity benefits accruing to domestic firms with the same sector. Through informal contacts and turnover of workers trained by foreign investors, domestic firms can enhance their productivity, if — and this is an important if — they are capable of absorbing the knowledge available. $^{4}$

In the analysis based on firm-level data, the charge has been led by Ann Harrison who, with several colleagues over the years and using data from different countries, has presented evidence that suggests that, at least in the short-run, FDI actually hurts local entrepreneurs rather

\footnotetext{
${ }^{4}$ In principle, such spillovers need not be restricted to firms with the same sector since general techniques, such as management methods, quality control, worker training, packaging, and marketing and distribution, could be useful to any firm. Indeed, the value of such general techniques may be large and Jane Jacobs (1969) argues that cities are efficient production agglomerations precisely because they facilitate such knowledge diffusion. However, we know little about such knowledge transfers, since the literature has focused on within sector effects.
} 
than raising their level of productivity through "spillovers" of knowledge. In Mona Haddad and Harrison (1993) and Brian Aitken and Harrison (1999), the evidence is that a larger foreign presence in the sector is associated with lower domestic productivity. Domestic firms that compete directly with the foreign investor may lose market share and, left stranded with excess capacity, experience a decline in the productive use of their resources.

Negative externalities may also arise where foreign investors increase the demand for scarce resources, such as skilled labor and domestic credit, and hence raise production costs. Robert Feenstra and Gordon Hanson (1996 and 1997) argue that foreign investors will use a more skill-intensive technology than the typical domestic investor and hence raise the wages of skilled workers, a proposition for which they find support in Mexican data. Harrison and Margaret McMillan (2003) highlight a different channel of influence. They note that "foreign" investors often finance their investments by borrowing in domestic markets. Where, as in many developing economies, domestic companies are already credit rationed, foreign firms aggravate the degree of rationing. They find evidence for preemption of domestic credit by foreign investors in Cote d'Ivoire.

Firm-level evidence for positive externalities from FDI typically come from high absorptive capacity settings such as Taiwan, China, the coastal provinces of China, the German and U.K. manufacturing sectors, and smaller European economies such as Ireland and Belgium (World Bank 2001). Jonathan Haskel, Sonia Pereira, and Matthew Slaughter (2002) undertake an extensive analysis of a panel of U.K. firms and reach several interesting conclusions. They find evidence for productivity spillovers within a given sector; in magnitude the spillover would account for about 5 percent of U.K. productivity growth and, the authors conclude, was insufficient to justify the subsidies provided to foreign investors. Lee Branstetter (2000) finds 
that Japanese firms investing in the United States enhanced their knowledge while at the same time benefiting U.S. firms - another example suggesting that knowledge spillovers are most active when firms have strong absorptive capacity. For the Chinese coastal provinces, for example, the finding is that FDI does help growth, but particularly so in locations with good infrastructure and superior human capital (Mody and Fang-Yi Wang 1997). Moreover, FDI and the supporting infrastructure and human capital appear to stimulate each other.

\section{Vertical Spillovers}

Early case-study research on spillovers from FDI had focused on backward linkages developed by foreign investors (e.g., Sanjaya Lall 1980) but firm-level panel data studies shifted attention to horizontal spillovers. With the continued finding of limited horizontal spillovers in most developing economies, interest in "vertical" spillovers has been renewed. Is productivity enhanced in sectors that supply to foreign investors? In a vertical relationship, the foreign investor has an incentive to transfer technology and provide training to raise the supplier's productivity. Thus, where vertical relationships exist, we should expect spillovers to be significant—and, indeed, the limited evidence supports that presumption. However, in assessing the overall impact of FDI, it is necessary to also determine the fraction of FDI that generates significant backward linkages into the domestic economy. The evidence suggests that local infrastructure and capabilities are important for the establishment of backward linkages.

For firms in Lithuania, Smarzynksa (2002) finds no horizontal spillovers from foreign investors, in line with research reported above, but she does find that "upstream" producers (suppliers) have increasingly higher productivity as the share of foreign investors in the "downstream" (customer) sectors increases. This is consistent with spillovers through backward 
linkages. However, she notes that the evidence is also consistent with the possibility of increased competition among upstream producers that weeds out low productivity producers-and, hence, the higher observed productivity is an artifact arising from firm exit rather than a genuine rise in productivity. She further notes that, while it is difficult to distinguish between the two competing possibilities, such a distinction is critical since the policy implications arising from the alternatives are quite different. Garrick Blalock and Paul Gertler (2003) address this question. They also find evidence of spillovers in backward linkage relationships. Moreover, they find supplier sectors have a lower, not higher, degree of concentration as the foreign presence increases in downstream sectors. They argue that foreign investors have an incentive to enhance productivity of multiple suppliers to minimize the risk of being held hostage, even though some of the benefits of upgraded suppliers may accrue to their competitors.

Of interest, then, are the factors that contribute to the development of backward supply linkages. It is likely that economic activities that require strong backward linkages also imply costly investment in training. When this is so, the potential investor may choose not to invest at all (Andres Rodriguez-Claire 1996). Thus, in low income economies with weak institutions, FDI is likely to be directed towards "enclave" sectors, such as extractive industries, that generate few backward linkages. The empirical evidence supports this conjecture. Rene Belderbos, Giovanni Capannelli, and Kyoji Fukao (2001) examine the extent of backward linkages established by Japanese investors in different countries. They find, for example, that while 80 percent of inputs are sourced domestically when they operate in the United States, the share of domestic inputs is considerably lower in developing economies. A more formal examination of the determinants of the share of local inputs shows that the quality of local infrastructure and capabilities of local suppliers is crucial in determining the extent of backward linkages. They note, further, that 
imposition of local content requirements either has the effect of Japanese producers establishing their own input supply factories or of dissuading firms from investing in that country.

Thus, whether we consider horizontal or vertical spillovers, the role of domestic capabilities appears to be crucial. Studies using aggregate data also conclude that the effectiveness of FDI depends on the country circumstances. Eduardo Borensztein, Jose De Gregorio, and Jong-Wha Lee (1998) find that FDI spurs growth where complementary human capital is of high quality and V.N.Balasubramanyam, M. Salisu, and David Sapsford (1991) find that the benefits of FDI accrue in countries with a strong export-orientation and not where import-substitution is the dominant strategy. Laura Alfaro, Areendam Chanda, Sebnem Kalimbli-Ozcan, and Selin Sayek (2003) find complementarity with financial development. However, Maria Carkovic and Ross Levine (2002) are skeptical even of these more nuanced findings. Using an econometric technique that controls for country fixed-effects and simultaneous determination of FDI and growth, they conclude (p. 3) that "the data do not suggest a strong independent impact of FDI on economic growth."

\section{Mergers and Acquisitions}

Finally, in view of the importance of cross-border mergers and acquisitions, consider briefly their impact on productivity. The evidence, unfortunately, is limited. Business academics are "dubious" with respect to the benefits of the megamergers that drove FDI flows in the later part of the 1990s (see, for example, Pankaj Ghemawat and Fariborz Ghadar 2000). Though, in line with the general literature on domestic mergers and acquisitions, most studies remain inconclusive, one study does argue that the international competition for corporate control in the U.S. has helped discipline managers (Jun-Koo Kang 1993). 
In developing countries, potential gains arise from the foreign purchase of state-owned assets, where domestic residents and entrepreneurs do not have sufficient financial resources and/or management experience to operate large-scale enterprises. Stanislaw Uminski (2001) reports significant gains from privatization in Poland, for example. Benefits, in the form of lower spreads charged, have also been documented following foreign ownership of domestic banks (see, for example, a review of earlier literature and new findings in Maria Soledad Martinez Peria and Mody forthcoming). However, aside from the one-time gain, which is undoubtedly important, further improvements in productivity will require an appropriately competitive and regulatory environment and foreign ownership is unlikely to be sufficient.

The opposite concern has, however, been sometimes expressed-i.e., foreign ownership through mergers and acquisitions may be harmful. Based on research by Assaf Razin and his colleagues, Loungani and Razin (2001) are concerned that foreign investors may "skim the cream":

Through FDI, foreign investors gain crucial inside information about the productivity of the firms under their control. This gives them an informational advantage over "uninformed" domestic savers, whose buying of shares in domestic firms does not entail control. Taking advantage of this superior information, foreign direct investors will tend to retain high-productivity firms under their ownership and control and sell lowproductivity firms to the uninformed savers. As with other adverse-selection problems of this kind, this process may lead to overinvestment by foreign direct investors.

Paul Krugman (1998) expressed concern about "fire sales" of domestic assets in the context of the Asian crises. He suggested that domestic owners are likely to be better informed about their businesses and, hence, about how to revive them following the sharp downturn experienced. However, because of the severe credit constraints faced by them, they would, in some instances, be forced to sell their assets at "fire sale" prices, an outcome that would not only be to the detriment of the sellers but also inefficient for the economy. Shoko Negishi and I, 
however, found little empirical support for this hypothesis (Mody and Negishi 2001) and conclude that the sectoral and country pattern of mergers and acquisitions following the crisis was likely prompted by the opportunities arising from the policy reform efforts.

This review of the micro evidence on the role of FDI is consistent with the preceding discussion on macro trends of FDI destinations. As the data showed, FDI flows have been directed towards environments with higher per capita incomes and better growth opportunities. The micro level studies bear out that productivity gains from FDI are greater the better the absorptive capacity of the domestic economy.

\section{Policy and Regulatory Matters}

Removing the obstacles to operations by foreign investors without going overboard in favoring them is the challenge that faces those who regulate FDI today. This is an evolution from the 1970s and 1980s when national authorities required foreign investors to undertake activities with possible developmental spillovers-sourcing of domestic inputs, exporting output to generate scarce foreign exchange, and training domestic workers. Such performance requirements (see Table 1) came to be viewed as onerous by investors and, along with other entry barriers in the manufacturing sector, are being voluntarily phased out, with commitments codified under the WTO's agreement on Trade-Related Investment Measures (TRIMs). In the 1990s, attention shifted to entry barriers that foreign investors faced in the services sectors and these are being gradually lowered primarily through the General Agreement on Trade in Services (GATS). But as deterrents to FDI have been scaled back, concerns have also arisen about the spread of fiscal and regulatory incentives to attract FDI. Today, a patchwork of FDI policy exists 
through bilateral and multilateral agreements: deterrents and incentives are not typically dealt under a unified framework or a coordinated policy or institutional initiative.

Table 1: International FDI Policies: From Old to New Concerns

\begin{tabular}{|l|l|l|}
\hline Concerns & \multicolumn{1}{|c|}{ Deterrents to FDI } & \multicolumn{1}{c|}{ FDI Incentives } \\
\hline Old & $\bullet$ Performance Requirements (TRIMs) & \\
\hline New & $\bullet$ Threat of Expropriation (Bilateral Treaties) & \\
& $\bullet$ Insufficient Transparency of Rules & $\bullet$ Race to the bottom; \\
& & $\bullet$ Transferring rents to foreigners. \\
\hline
\end{tabular}

To the extent progress on the FDI policy agenda is achieved, will that progress change the fact that half of all developing country FDI goes to three countries? Or, will productivity benefits of FDI increase? The forces described above, leading to the concentration of FDI in host economies with high absorption capacity, are powerful — and appear to have been only marginally influenced by the huge liberalization of FDI policy that did occur in the last two decades.

In this section, I discuss policy and regulatory matters with respect to FDI under three headings: (a) current cross-country disciplines on FDI; (b) host country incentives to attract FDI; and (c) a forward-looking multilateral agenda on FDI.

\section{Cross-Country Disciplines on FDI}

Cross-country policy measures to channel FDI include bilateral tax and investment treaties, regional agreements, and multilateral rules; the multilateral rules at the present time 
operate principally under the auspices of the World Trade Organization (WTO). In common, they seek to create a level playing field for foreign investors. In particular, "national treatment" implies that foreign firms should have the same rights of establishment and operation as do national firms.

Bilateral treaties are, perhaps, by far the most prevalent form of FDI regulation. In a recent analysis of tax treaties (also referred to as double-tax treaties), Bruce Blonigen and Ronald Davies (2002) note that more than 2000 such treaties are in existence (an update of the numbers of treaties is provided by UNCTAD's World Investment Report). Blonigen and Davies find, for the period 1982-1992, that U.S. firms undertook less not more FDI in countries with which the U.S. had recently concluded a treaty. The implication is that, where no tax treaties exist, multinationals use concessions and loopholes in foreign tax systems to their advantage. Tax treaties reduce the possibilities of tax evasion through, for example, transfer pricing and the use of "tax havens." The study thus lends credence to the view that multinational firms can and do bypass national tax systems and that bilateral treaties are desirable from a revenue perspective and, possibly, for the efficient allocation of investment.

Bilateral investment treaties have investor protection as their goal. These have also proliferated, especially in the 1990s, rising, as Mary Hallward-Driemeier (2003) notes from 470 in 1990 to almost 2000 in number by the year 2000, covering half of all FDI flows from OECD to developing economies. In an econometric study, she finds, however, that such treaties have had virtually no influence on increasing the flow of FDI to signatory hosts. Investment treaties, therefore, are not a substitute for domestic laws protecting property rights. Countries in SubSaharan Africa, for example, have entered into several agreements to protect investors but have had limited success in attracting FDI; in contrast, Brazil, a major FDI recipient, has not ratified a 
single investment treaty. Cuba does not have a treaty with either Canada or Mexico, its main foreign investors - almost two-thirds of the countries with which it does have a treaty make no investment in that country. Gaetan Verhoosel (2003) points out the investment treaties typically refer to, an often vaguely defined, "international law" as the standard by which possible expropriation is to be assessed and investors have recourse to various international dispute resolution forums. Drawing on several examples, Hallward-Driemeier (2003, p. 7) suggests that foreign investors could misuse the treaties to protect themselves even against normal commercial risks.

Beyond bilateral treaties lie regional agreements, which have also proliferated in recent years. Regional rules for investment could bolster investment flows in the short-run by committing countries to stable policy regimes (Raquel Fernandez and Jonathan Portes 1998) and by providing access to larger markets, but they are also likely to divert FDI from nonparticipating countries. It has been observed that FDI typically increases when a country joins a regional common market (see, for example, John Dunning 1997 and Ray Barrell and Nigel Pain 1998 for evidence on Europe and Anne Krueger 2000 for Mexico following its entry into North American Free Trade Agreement (NAFTA)). The difficulty, however, arises in attributing the observed increase to the regional agreement. In the case of Mexico, for example, a 1993 foreign investment liberalization law that just predated NAFTA, the ongoing worldwide boom in FDI, and the general shift in Mexico's economic policies all contributed to increased foreign investment received (see Krueger 2000). UNCTAD (2003, p. 58) concludes that "the definitive study of NAFTA's impact on FDI has yet to be done." Even careful econometric analysis will find it difficult to disentangle the various effects. Eduardo Levy Yeyati, Ernesto Stein, and Christian Duade (2002) find that a host country receives more FDI if it is a member of a regional 
trading arrangement, not only from source countries under the same arrangement but also from other source countries presumably attracted by the larger market size that can be accessed. At the same time, countries that are not members of regional arrangements receive somewhat lower FDI, suggesting a diversion of FDI. However, V.N. Balasubramanyam, David Sapsford, and David Griffiths (2002) conclude that when a full range of explanatory variables reflecting host and source country considerations is included, the regional agreement is found to have no independent effect. Thus, the evidence is, at best, inconclusive.

Finally, on the multilateral front, World Trade Organization (WTO) remains the primary forum for advancing multilateral disciplines in investment. These include reduction of subsidies that favor exports, less discrimination against foreign firms with respect to rights of establishment and market access, and protection of investors against expropriation. Export processing zones that offer subsidies not available for other domestic activities are inconsistent with WTO standards and such subsidies are to be phased out over the coming years. John Mutti (2002) notes that this is a complex exercise with the phasing out to occur more rapidly where a country accounts for more than 3.25 percent of world market share in particular product categories; at the other end, the least developed countries (countries with an annual per capita income of less than $\$ 1000$ ) will be allowed to retain their subsidies for the present.

The General Agreement on Trade in Services (GATS) promotes greater international trade in services and forms the umbrella for enhancing the rights of foreign firms to, among other things, national treatment. Investment regimes with respect to manufacturing establishments have been largely liberalized and hence it is in service sectors, with their myriad regulatory barriers to entry, that a more open environment is needed. However, as Pierre Sauve and Christopher Wilke (2000) note and as was discussed above, despite the remaining barriers, 
international investment flows to the services sectors have already been large. Thus, Sauve and Wilke (2000) conclude that there is no compelling case for a more aggressive approach to the achieving multilateral disciplines for investment regime.

To summarize, the international regime governing investment flows remains a patchwork of bilateral, regional, and multilateral treaties and rules. While this is apparently an undesirable state of affairs - undesirable because investment is likely to be misallocated in the attempt to conform to the patchwork - policymakers are not overly concerned. This is largely attributable to a strong unilateral drive on the part of a large majority of countries to reduce entry barriers (see UNCTAD 2003, which documents the continued reduction of barriers to FDI). Looking ahead, multilateral rules may have a unifying role to play in the investment arena. However, both because the gains from the pursuit of an active multilateral agenda are unclear and because the various interested parties have differing views on priorities, multilateral efforts in the area of foreign investment have not been and are not expected to be forcefully pursued. Not surprisingly, the Doha round, even before it was set back, had a modest agenda for investment flows. ${ }^{5}$ The more ambitious OECD-sponsored Multilateral Agreement on Investment failed because in terms of investment protection it offered less than the existing bilateral investment treaties, potential signatories worried about free-riding by non-signatories (who would gain from the most favored nation status through WTO disciplines), and labor and environmental groups worried about the growing power of multinational corporations (World Bank 2003, Box 4.2).

\section{Host Country Incentives}

${ }^{5}$ A potentially useful initiative of the Doha round is the effort to increase transparency in rules and regulations governing FDI, including procedures for consultation and notification. 
Much of an earlier debate on policy towards FDI centered on the desirability of "performance requirements," or obligations, such as export targets and training of domestic nationals, that the foreign investor was required to fulfill. The premise was that an active government effort was required to realize the externalities from foreign investment. Thus, part of the FDI folklore was Singapore's success in having its nationals trained by multinational firms, including large numbers not directly employed in those firms. However, multinationals themselves never favored performance requirements and, as the competition for FDI increased, such requirements have gradually been phased out in many countries. Interestingly, despite declining in policy respectability, the analytical case for performance requirements has not disappeared. James Markusen (1998), for example, argues that foreign investment flows from market distortions generate significant rents and it is legitimate for the host country to extract some part of these rents. ${ }^{6}$

The policy pendulum, however, has swung to the other end. The concern now is with excessive subsidies to attract foreign investors. To assess this concern, we need answers to three questions: (a) Are governments indeed in a race to attract foreign investors? (b) If they are, do incentives work? And (c) how, if at all, should public policy respond to the possibility of excessive competition for foreign investment?

A comprehensive measure of incentives is difficult to compile and, to my knowledge, does not exist. Considerable effort has, however, been devoted recently to one, possibly

\footnotetext{
${ }^{6}$ Markusen (1998) refers specifically to the host country's obligation to protect a foreign investor's intellectual property but the right also to bargain for the rents from such property. This is an important policy issue in the context of life-saving drugs. Whether a host country could bargain for the more typical commercial technologies is an open question, but seems unlikely.
} 
significant, element of the incentive package, namely, the effective tax obligation of a foreign investor. A July 2000 study by the United Nations Conference on Trade and Development (UNCTAD) surveyed 45 countries from all regions of the world and concluded: "Nearly all countries surveyed offer incentives that target specific sectors. Regional incentives aimed at assisting the economic development of rural or underdeveloped areas are also prevalent in 70 percent of the countries surveyed." The incentives, the UNCTAD study reports, are offered principally through various tax breaks, including tax holidays, accelerated depreciation, and allowances for training and R\&D.

The most plausible way to aggregate these tax incentives is to consider the effective corporate tax paid by foreign firms. It is not straightforward to obtain such rates and Mutti (2002) surveys several alternative measures. He reaches three conclusions of interest.

- Between 1984 and 1996, statutory corporate tax rates typically declined around the world. Effective tax rates (tax collected/GDP) also declined but to a smaller extent as tax bases broadened.

- Tax rates fell especially in countries with higher rates. Rates were reduced by about 15 percentage points in countries with high rates (statutory rates greater than 45 percent) and by 4 percentage points in countries with low rates.

- Much of the tax reduction during this period occurred between 1984 and 1992 and slowed down thereafter. After 1992, rate reduction in high rate countries (statutory rates higher than 35 percent after 1992) was only of the order of 4 percentage points, while rates remained broadly unchanged in low rate countries.

Thus, the finding is that rates fell sharply mainly to bring effective rates across countries closer to each other and have since stabilized. One explanation for the sharp decline in the years 
immediately following 1986 is a change in that year in U.S. policy towards multinationals that significantly reduced their tax burden. International tax competition then made high rates untenable.

How relevant is tax competition for location decisions by foreign investors? The evidence on this score is mixed and Mutti's (2002) recent discussion of the literature and his new results help clarify the reasons for the ambiguities in the econometric results. He points out that the implications of tax rates will vary with the nature of the foreign investment. An important difference in this regard is whether the investment is directed to serving the domestic market in the host country or is intended to produce goods for the world market. Mutti (2002) finds that export-oriented investment is most sensitive to tax rates. This conclusion is consistent with early results reported in Wheeler and Mody (1992), where we showed that though tax rates were not especially relevant for location decisions when the manufacturing sector as a whole was considered, they were influential in guiding investors in the electronics industry, a "footloose" industry in the terminology of those years seeking low cost production sites for assembling products destined for world markets. As countries have vied for such export-oriented foreign investment, tax competition has become a more salient policy issue.

What, then, is the advice to policymakers? An OECD study offers some useful pointers (OECD 2001). ${ }^{7}$ Since poor operating conditions act as the fundamental deterrents to foreign investment, improving those conditions should be the first order of business. Policymakers may be concerned that the fundamental structural reforms required to improve infrastructure and human capital will take too long and tax incentives offer a quick mechanism for bringing in

\footnotetext{
${ }^{7}$ See also Gordon Hanson (2001) for similar advice.
} 
needed foreign investment. Adoption of such an approach, however, requires credible evidence of positive externalities from foreign investment. Where such evidence does exist and is credible, the alternative of generally low tax rates, with a broader tax base, must be considered against selective incentives for foreign investors.

\section{A Forward-Looking Agenda}

So is there reason to pursue a bolder international approach? One possibility is to revive and give greater attention to the consideration of labor mobility, such as that already tabled under the GATS. The premise is that investment flows to developing countries will increase if migration - particularly of skilled workers—-from developing countries increases. On that relationship between migrants and investment, I believe, the empirical evidence is quite strong. A further, more speculative, assertion is that the quality of the capital flows, and hence their productivity, will also improve when accompanied by more mobile developing country workforce.

Arvind Panagariya (1999) has argued that developing countries should only agree to an international agreement on investment if there is a corresponding willingness on the part of developed nations to open their borders to migrants from developing countries. He offers two arguments in favor of this proposal. First, citing a study by Hamilton and Whalley (1984), he notes that worldwide gains from greater labor mobility are huge and they dwarf gains from other forms of liberalization. Second, the benefits of labor mobility will accrue principally to poorer countries and, hence, are desirable from an equity perspective. Panagariya (1999) is also not persuaded by claims that no political appetite exists for such initiatives. He interprets the history of the multilateral agreements, particularly recent agreements that have moved beyond the 
traditional trade agenda, as having evolved in an incremental fashion. He suggests, therefore, that an initial focus on the mobility of professionals is likely to be attractive to all, and will also allay fears of some developing countries who may be concerned themselves about supporting large numbers of unskilled migrants from less developed neighbors. Panagariya notes that such a vision is already reflected in the deliberations associated with GATS. ${ }^{8}$

More recently, Dani Rodrik (2002) has echoed Panagariya's analysis. Rodrik notes that even though goods and financial markets are not fully integrated, price differentials in those markets rarely exceed the ratio of 2:1. In contrast, wage differentials across countries are often of the order of 10:1. His "back-of-the-envelope" calculation for immigration equaling about 3 percent of the developed country workforce produces an annual gain of $\$ 200$ billion a year, almost all of it to developing countries. On the political economy of greater international mobility of labor, Rodrik also concludes, as Panagariya does, that political constraints are "malleable." He notes that those who oppose greater mobility of labor also oppose imports of labor-intensive products from developing countries but adequate mobilization of interested parties has been effective in reducing trade barriers. He proposes a temporary work visa scheme, though he would apply that to both skilled and unskilled workers. ${ }^{9}$

I would add one further consideration to this discussion. There is considerable evidence that labor flows will complement trade and investment flows. Hence, though the argument is sometimes stated in terms of "this" or "that," I believe that need not be the case. The political bargaining may still be conducted in terms of a "quid pro quo"- a more liberal investment

\footnotetext{
${ }^{8}$ Allison Young (2000) describes these deliberations.

${ }^{9}$ To enforce the temporary nature of the migration, he suggests that a portion of the migrant's earnings be withheld until return to the home country.
} 
regime only in return for greater labor mobility. However, the economic argument should consider the complementarities.

Recent research shows that international networks of mobile specialists facilitate trade and investment. Jim Rauch (1999) and Rauch and Vitor Trindale (2002) have found that networks of Chinese migrants boost trade especially in differentiated goods. Such goods are characterized by high transactions costs on account of the product-specific knowledge necessary to complete such trades and migrant networks, with their traditional mechanisms of communication and trust built on repeated transactions, reduce those transactions costs. Evenett (2001) analyzes the level of mergers and acquisitions completed by U.S. firms in different countries around the world. He finds that mergers and acquisitions are significantly higher in those countries where a leading U.S. law firm has a substantial and long-standing presence. He infers that the local knowledge acquired by these lawyers helps bridge the gap between their U.S. clients and the regulatory requirements of the host country. Finally, in my own ongoing work with Antonio Spilimbergo, international students are found to precede both trade and investment. We find, controlling for traditional determinants, that a country imports more and receives more foreign direct investment from a partner country if, in the preceding decade, the host had sent a larger number of students to that partner. Moreover, in line with Rauch's research, trade in differentiated goods is especially lifted by the flow of students.

In sum, this evidence is consistent with a view that large informational gaps exist when trading and investing across borders and direct human intervention is particularly effective in overcoming this barrier. The implication is that information deficiencies cannot be overcome in a mechanical manner by applying routine rules of decision-making. Rather, the ability of skilled individuals to solve complex problems in real time is necessary to strengthen trade and 
investment links. Thus, the movement of traders, skilled professionals, and students (who may either return to their home country or continue to work as professionals in the destination economy) helps negotiate and reconcile the cultural and institutional variance across nations and thus reduces transaction costs.

\section{Conclusions}

The dramatic spread of FDI in the 1990s was an important development that will have long-term value. The immediate benefits in the form of higher levels of domestic investment have largely materialized but other expected benefits - more rapid productivity growth and better corporate governance - have been slow to accrue in a broad range of settings and appear to have been significant mainly where domestic absorptive capacity is already high.

However, FDI has been a trusted source of capital during the turbulent nineties. During a period when portfolio flows boomed and then crashed, FDI remained a resilient form of external finance. Lipsey (2000) notes that during the Mexican and Asian crises, foreign investors maintained their capital expenditures and were able to redirect their sales from domestic to international markets, transferring the benefits of their own flexibility to the stressed domestic economies. This has prompted some to suggest that FDI should be bolstered, not by providing fiscal incentives, but by reducing the disadvantages it faces in relation to other forms of external capital. Kenneth Rogoff (1999), for example, argues that the current domestic and international policy regime favors debt over equity capital and measures to redress the balance would be beneficial to host countries and the world economy.

Substantial challenges remain in harnessing the true value of FDI for raising growth rates in developing economies, especially among the least developed (Sanjaya Lall 2000 and World 
Bank 2002). However, the aggressive use of subsidies is unlikely to be the route through which that objective is achieved. Cross-country disciplines through bilateral, regional, and multilateral efforts are important in reducing the distortions that lead to misallocation of capital but ultimately domestic efforts to raise absorptive capacity will be critical. Efforts to increase labor mobility, as forseen, for example, under GATS, could have a significant effect in raising the benefits from FDI as the more mobile labor serves to bridge the cultural, institutional, and contractual differences across nations. 


\section{References}

Aitken, Brian J. and Ann E. Harrison. 1999. "Do Domestic Benefit from Direct Foreign Investment? Evidence from Venezuela.” American Economic Review 89(3): 605-618.

Albuquerque Rui, Norman Loayza, and Luis Serven. 2002. "World Market Integration Through the Lens of Foreign Direct Investors." Presented at "The FDI Race: Who Gets the Prize? Is It Worth the Effort?" Washington D.C.: Inter-American Development Bank and the World Bank. Available on the web at http://www.iadb.org/res/publications/pubfiles/pubS-FDI.pdf

Alfaro Laura, Areendam Chanda, Sebnem Kalimbli-Ozcan, and Selin Sayek. 2003. "FDI Spillovers, Financial Markets, and Economic Development." IMF Working Paper WP/03/186, Washington D.C.: International Monetary Fund.

Balasubramanyam, V.N., M. Salisu, and David Sapsford. 1991. "Export Promotion, Import Substitution and Direct Foreign Investment in Less Developed Countries." In A. Koekkok and L.B.M. Mennes (eds.) International Trade and Global Development: Essays in Honour of Jagdish Bhagwati. London: Routledge.

Balasubramanyam, V.N., David Sapsford, and David Griffiths. 2002. "Regional Integration Agreements and Foreign Direct Investment: Theory and Preliminary Evidence." The Manchester School 70(3): 460-482.

Barrell, Ray and Nigel Pain. 1998. "Real Exchange Rates, Agglomerations and Irreversibilities: Macroeconomic Policy and FDI in EMU." Oxford Review of Economic Policy 14(3): 152-167.

Belderbos, Rene, Giovanni Capannelli, and Kyoji Fukao.2001. "Backward Vertical Linkages of Foreign Manufacturing Affiliates: Evidence from Japanese Multinationals." World Development 29 (1): 189-208.

Blalock, Garrick and Paul Gertler. 2003. "Technology from Foreign Direct Investment and Welfare Gains through the Supply Chain." Available on the web at: http://aem.cornell.edu/faculty_sites/gb78/wp/vfdi_04_27.pdf

Blonigen, Bruce and Ronald Davies. 2002. "Do Bilateral Treaties Promote Foreign Direct Investment?" National Bureau of Economic Research Working Paper 8834, Cambridge, MA.

Borensztein, E., J. De Gregorio, and J-W. Lee.1998. "How Does Foreign Direct Investment Affect Growth? Journal of International Economics 45(1): 115-135.

Bosworth, Barry and Susan Collins. 1999. "Capital Flows to Developing Economies: Implications for Saving and Investment." Brookings Papers on Economic Activity 1: 143-169.

Branstetter, Lee. 2000. "Is Foreign Direct Investment a Channel of Knowledge Spillovers? Evidence from Japan's FDI in the United States.” NBER Working Paper 8015, Cambridge MA. 
Calderon, Cesar, Norman Loayza, and Luis Serven. 2002. "Greenfield FDI vs. Mergers and Acquisitions: Does the Distinction Matter?” World Bank, Washington D.C.

Carkovic, Maria and Ross Levine. 2002. "Does Foreign Direct Investment Accelerate Economic Growth?" University of Minnesota.

Caves, Richard. 1999. "Spillovers from Multinationals in Developing Countries: The Mechanisms at Work." William Davidson Institute Working Paper 247. Ann Arbor, Mich.

Clemens, Michael A. and Jeffrey G. Williamson. 2000. "Where Did British Foreign Capital Go? Fundamentals, Failures, and the Lucas Paradox." National Bureau of Economic Research Working Paper 8028, Cambridge MA.

Dunning, John H. 1997. “The European Internal Market Programme and Inbound Foreign Direct Investment." Journal of Common Market Studies 35: 1-30.

Evenett, Simon J. 2001. "Do All Networks Facilitate International Commerce? The Case of US Law Firms and the Mergers and Acquisitions Wave of the Late 1990s." Available at www.ssrn.com.

Feenstra, Robert and Gordon Hanson. 1996. "Foreign Investment, Outsourcing and Relative Wages.” In R.C. Feenstra, G.M. Grossman, and D.A. Irwin, eds., Political Economy of Trade Policy: Essays in Honor of Jagdish Bhagwati, Cambridge: MIT Press.

Feenstra, Robert and Gordon Hanson. 1997. "Foreign Direct Investment and Relative Wages: Evidence from Mexico's Maquiladoras.” Journal of International Economics 42: 371-394.

Fernandez, Raquel and Jonathan Portes. 1998. "Returns to Regionalism: An Analysis of NonTraditional Gains from Regional Trade Arrangements." World Bank Economic Review 12(2): 197-220.

Ghemawat, Pankaj and Fariborz Ghadar. 2000. "The Dubious Logic of Global Megamergrs." Harvard Business Review 78(4): 64-74.

Gould, David. 1994. "Immigrant links to the home country: empirical implications for U.S. bilateral trade flows." Review of Economics and Statistics 76:302-16.

Haddad, Mona and Ann Harrison. 1993. "Are There Spillovers from Direct Foreign Investment?" Journal of Development Economics 42: 51-74.

Hallward-Driemeier, Mary. 2003. "Do Bilateral Investment Treaties Attract FDI? Only a Bit...And They Could Bite." Washington D.C.: World Bank. Available on the web at http://econ.worldbank.org/files/29143_wps3121.pdf. 
Hamilton, B. and John Whalley. 1984. "Efficiency and Distributional Implications of Global restrictions on Labor Mobility: Calculations and Policy Implications." Journal of Development Economics 14(1): 61-75.

Haskel, Jonathan E., Sonia Pereira, and Matthew Slaughter. 2002. "Does Inward Foreign Direct Investment Boost the Productivity of Domestic Firms?" NBER Working Paper 8724, January 2002.

Hanson, Gordon H. 2001. "Should Countries Promote Foreign Direct Investment?" G-4 Discussion Paper Series 9, United Nations, New York and Geneva.

Harrison, Ann E. and Margaret S. McMillan. 2003. "Does Direct Foreign Investment Affect Firms' Credit Constraints?” Journal of International Economics 61(1): 73-100.

Jacobs, Jane. 1969. The Economy of Cities, New York: Random House.

Kang, Jun-Koo. 1993. "The International market for Corporate Control: Mergers and Acquisitions of U.S. Firms by Japanese Firms." Journal of Financial Economics 34(3): 345-371.

Krueger, Anne. 2000. “NAFTA's Effects: A Preliminary Assessment.” World Economy 23(6): 761-775.

Krugman, Paul. 1998. "Fire-Sale FDI." Available on the web at http://web.mit.edu/Krugman/www/FIRESALE.Htm.

Lall, Sanjaya. 1980. "Vertical Inter-Firm Linkages in LDCs: An Empirical Study." Oxford Bulletin of Economics and Statistics 42: 203-226.

Lall, Sanjaya. 2000. "Evaluation of Promotion and Incentive Strategies for FDI in Sub-Saharan Africa." Oxford University.

Levy Yeyati, Eduardo, Ernesto Stein, and Christian Duade. 2002. "Regional Integration and the Location of FDI." Presented at "The FDI Race: Who Gets the Prize? Is It Worth the Effort?" Washington D.C.: Inter-American Development Bank and the World Bank. Available on the web at http://www.iadb.org/res/publications/pubfiles/pubS-FDI-11.pdf.

Lipsey, Robert. 2000. "Foreign Direct Investors in Three Financial Crises." National Bureau of Economic Research Working Paper 8084, Cambridge MA.

Lipsey, Robert and Zadia Feliciano. 2002. "Foreign Entry into U.S. Manufacturing by Takeovers and the Establishment of New Firms." National Bureau of Economic Research Working Paper 9122, Cambridge MA.

Loungani, Prakash and Assaf Razin. 2001. "How Beneficial is Foreign Direct Investment for Developing Countries?" Finance and Development 38(2): 
Loungani, Prakash, Ashoka Mody, and Assaf Razin. 2002. "The Global Disconnect: The Role of Transactional Distance and Scale Economies in Gravity Models." Forthcoming in the Scottish Journal of Political Economy.

Lucas, Robert. 1990. "Why Doesn't Capital Flow from Rich to Poor Countries?" American Economic Review 80: 92-96.

Markusen, James R. 1998. "Multilateral Rules on Foreign Direct Investment: The Developing Countries' Stake.” Department of Economics, University of Colorado, Boulder.

Martinez Peria, Maria Soledad and Ashoka Mody. Forthcoming. How Foreign Participation and Market Concentration Impact Bank Spreads: Evidence from Latin America," Journal of Money, Credit and Banking.

Mody, Ashoka and Fang-Yi Wang. 1997. "Explaining Industrial Growth in Coastal China: Economic Reforms...and What Else?" World Bank Economic Review 11(2): 293-325.

Mody, Ashoka and Krishna Srinivasan. 1998. "U.S. and Japanese Investors: Do the March to the Same Tune?” Canadian Journal of Economics 31: 778-799.

Mody, Ashoka, Susmita Dasgupta, and Sarbajit Sinha. 1999. "Japanese Multinationals in Asia: Drivers and Attractors.” Oxford Development Studies 27(2): 149-164.

Mody, Ashoka and Shoko Negishi. 2001. "The Role of Cross-Border Mergers and Acquisitions in Asian Restructuring." In Stijn Claessens, Simeon Djankov, and Ashoka Mody (eds.) Resolution of Financial Distress: An International Perspective on the Design of Bankruptcy Laws. WBI Development Studies, The World Bank, Washington D.C.

Mody, Ashoka and Antu Murshid. 2002. "Growing Up with Capital Flows." IMF Working Paper WP/02/75, Washington D.C.

Mutti, John. 2002. Foreign Direct Investment, Taxes, and Tax Competition. Department of Economics, Grinnell College, Grinnell, IA.

OECD. 2001. Corporate Tax Incentives for Foreign Direct Investment. OECD Tax Policy Studies 4, Organization for Economic Co-Operation and Development, Paris.

Panagariya, Arvind. 1999. "The Millenium Round and Developing Countries: Negotiating Strategies and Areas of Benefits." University of Maryland, College Park. Can be found at: http://www.bsos.umd.edu/econ/panagariya/apecon/polpaper.htm.

Rauch, James. 1999. "Networks Versus Markets in International Trade." Journal of International Economics 48:7-35. 
Rauch, James and Vitor Trindale. 2002. "Ethnic Chinese Networks in International Trade." Review of Economics and Statistics 84:116-130.

Rodriguez-Clare, Andres. 1996. "Multinationals, Linkages, and Economic Development." American Economic Review 86(4): 852-873.

Rodrik, Dani. 2002. "Feasible Globalizations." Centre for Economic Policy Research Discussion Paper 3524, London.

Rogoff, Kenneth. 1999. "International Institutions for Reducing Global Financial Instability." Journal of Economic Perspectives 13(4): 21-42.

Sarno, Lucio and Mark P. Taylor. 1999. "Hot Money, Accounting Labels and the Permanence of Capital Flows to Developing Countries: An Empirical Investigation." Journal of Development Economics 59: 337-364.

Sauve, Pierre and Christopher Wilke. 2000. "Investment Liberalization in GATS." In Pierre Sauve and Robert M. Stern (eds.) GATS 2000: New Directions in Services Trade Liberalization. Center for Business and Development, Harvard University, and Brookings Institution Press, Washington D.C.

Smarzynska, Beata. 2002. "Does Foreign Direct Investment Increase the Productivity of Domestic Firms? In Search of Spillovers through Backward Linkages." World Bank Policy Research Paper 2923, Washington D.C.

Smarzynska, Beata and Shang-Jin Wei. 2002. "Corruption and Cross-Border Investment: FirmLevel Evidence." Presented at "The FDI Race: Who Gets the Prize? Is It Worth the Effort?" Washington D.C.: Inter-American Development Bank and the World Bank. Available on the web at http://www.iadb.org/res/publications/pubfiles/pubS-FDI-7.pdf

Uminski, Stanislaw. 2001. "Foreign Capital in the Privatization Process of Poland." Transnational Corporations 10(3): 75-94.

United Nations Conference on Trade and Development. 2000. "Tax Incentives and Foreign Direct Investment: A Global Survey.” New York and Geneva.

United Nations Conference on Trade and Development. 2002. "FDI Downturn in 2001 Touches Almost All Regions." UNCTAD Press Release TAD/INF/2850. Available at: http://www.unctad.org/en/press/pr0236en.htm.

United Nations Conference on Trade and Development. 2003. World Investment Report. Geneva.

Verhoosel, Gaeten. 2003. "The Use of Investor-State Arbitration Under Bilateral Investment Treaties To Seek Relief for Breaches of WTO Laws." Journal of International Economic Law 6(2): 493-506. 
Young, Allison. 2000. "What Next for Labor Mobility under GATS?” In Pierre Sauve and Robert M. Stern (eds.) GATS 2000: New Directions in Services Trade Liberalization. Center for Business and Development, Harvard University, and Brookings Institution Press, Washington D.C.

Wheeler, David and Ashoka Mody. 1992. International Investment Location Decisions: the case of U.S. Firms.” Journal of International Economics 33: 57-76.

World Bank. 2001. Global Development Finance: Building Coalitions for Effective Development Finance. Washington D.C.

World Bank. 2002. Global Development Finance. Washington D.C. 


\section{Appendix: Data Sources and Country Coverage in Figures 5 and 6}

Data on FDI inflows, GDP, and population were obtained from the World Bank's World Development Indicators. M\&A sales statistics were obtained from the United Nations Conference on Trade and Development (UNCTAD). Countries' income groups used in Figures 5 and 6 correspond to the World Bank's GNI per capita classification.

While Figures 1 through 4 use global or country-group totals, the more country-specific analysis in Figures 5 and 6 dropped small countries (with a population of less than 1 million inhabitants) and transition economies (which had limited data in the 1990s and, moreover, experienced large fluctuations in both FDI and GDP). The list of the countries used in the country-specific analysis, by country-group (income and Top 10 FDI recipients), is provided below.

\begin{tabular}{|c|c|c|c|c|}
\hline Low & & Mid-low & Mid-high & Top 10 (ranked) \\
\hline Angola & Madagascar & Algeria & Argentina & China \\
\hline Bangladesh & Malawi & Bolivia & Botswana & Brazil \\
\hline Benin & Mali & Brazil & Chile & Mexico \\
\hline Burkina Faso & Mauritania & China & Costa Rica & Argentina \\
\hline Burundi & Mongolia & Colombia & Malaysia & Malaysia \\
\hline Cambodia & Mozambique & Dominican Rep & Mauritius & Poland \\
\hline Cameroon & Nepal & Ecuador & Mexico & Chile \\
\hline CAR & Nicaragua & Egypt & Oman & Thailand \\
\hline Chad & Niger & El Salvador & Panama & Venezuela \\
\hline Congo & Nigeria & Guatemala & Poland & Colombia \\
\hline Cote D'Ivoire & Pakistan & Honduras & Uruguay & \\
\hline Ethiopia & Papua New G. & Iran & Venezuela & \\
\hline Gambia & Rwanda & Jamaica & & \\
\hline Ghana & Senegal & Jordan & & \\
\hline Guinea & Sierra Leone & Morocco & & \\
\hline Guinea-Bissau & Tanzania & Paraguay & & \\
\hline Haiti & Togo & Peru & & \\
\hline India & Uganda & Philippines & & \\
\hline Indonesia & Viet Nam & Sri Lanka & & \\
\hline Kenya & Zambia & Swaziland & & \\
\hline Lao & & Thailand & & \\
\hline Les otho & & Tunisia & & \\
\hline Liberia & & Turkey & & \\
\hline
\end{tabular}


Figure 1. FDI Inflows \& Cross-border M\&A Sales (billions of USD), 1980-2002

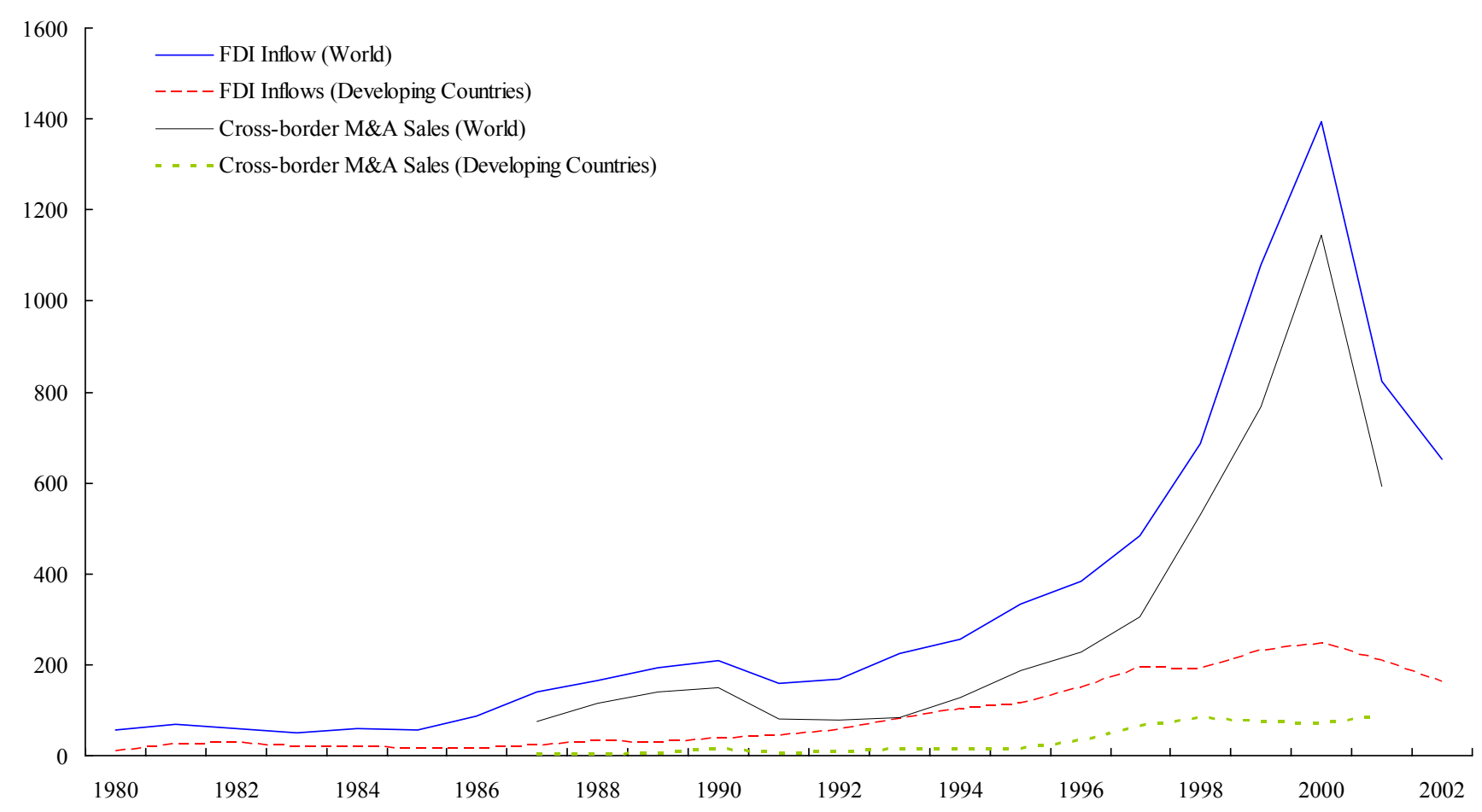

Figure 2. FDI Inflows as a Percentage of

GDP

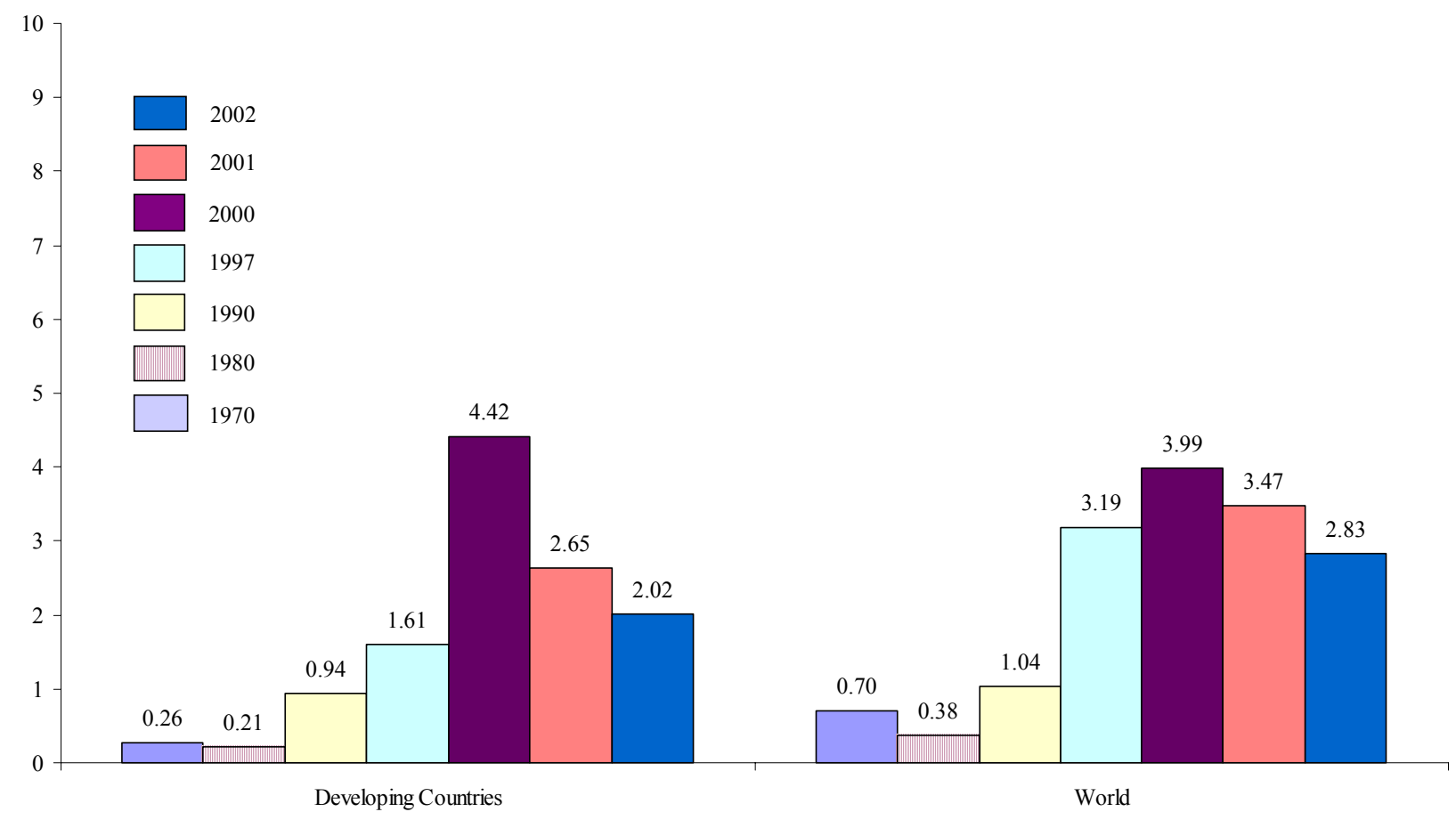


Figure 3. Cross-border M\&As by Industry of Seller

1987

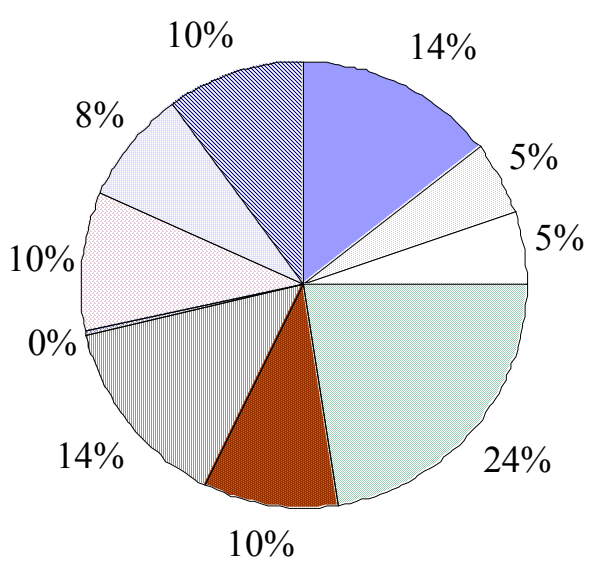

2000

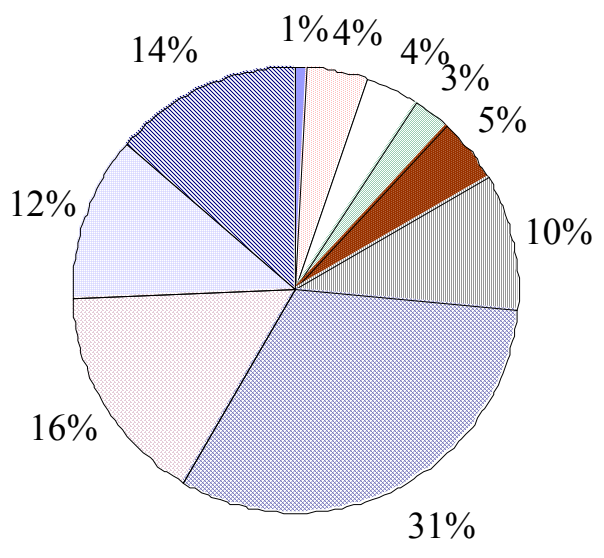

$\square$ Primary Sector

$\square$ Coke, petroleum and nuclear fuel

Electrical and electronic equipment

$\square$ Transport, storage and communications

$\square$ Business services
1993

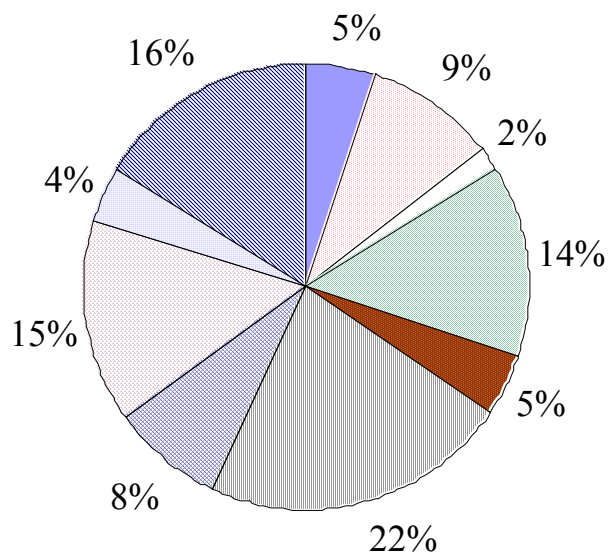

2001

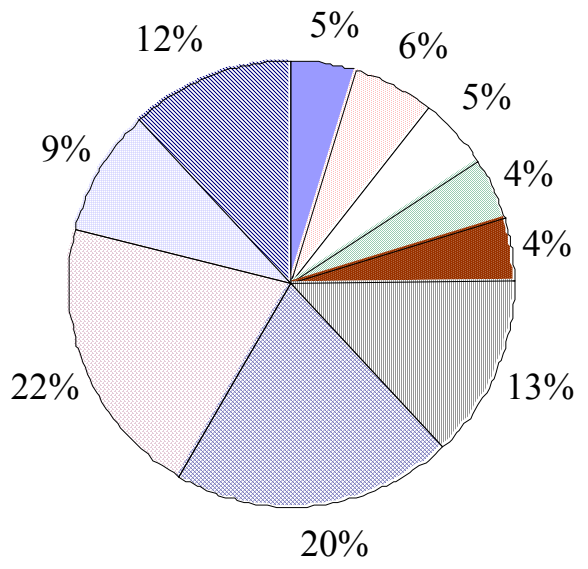

$\square$ Food, beverages and tobacco

$\square$ Chemicals and chemical products

Other manufacturing

$\square$ Finance

$\square$ Other Services 
Figure 4. Developing Country Shares in the Global Economy: Selected Indicators

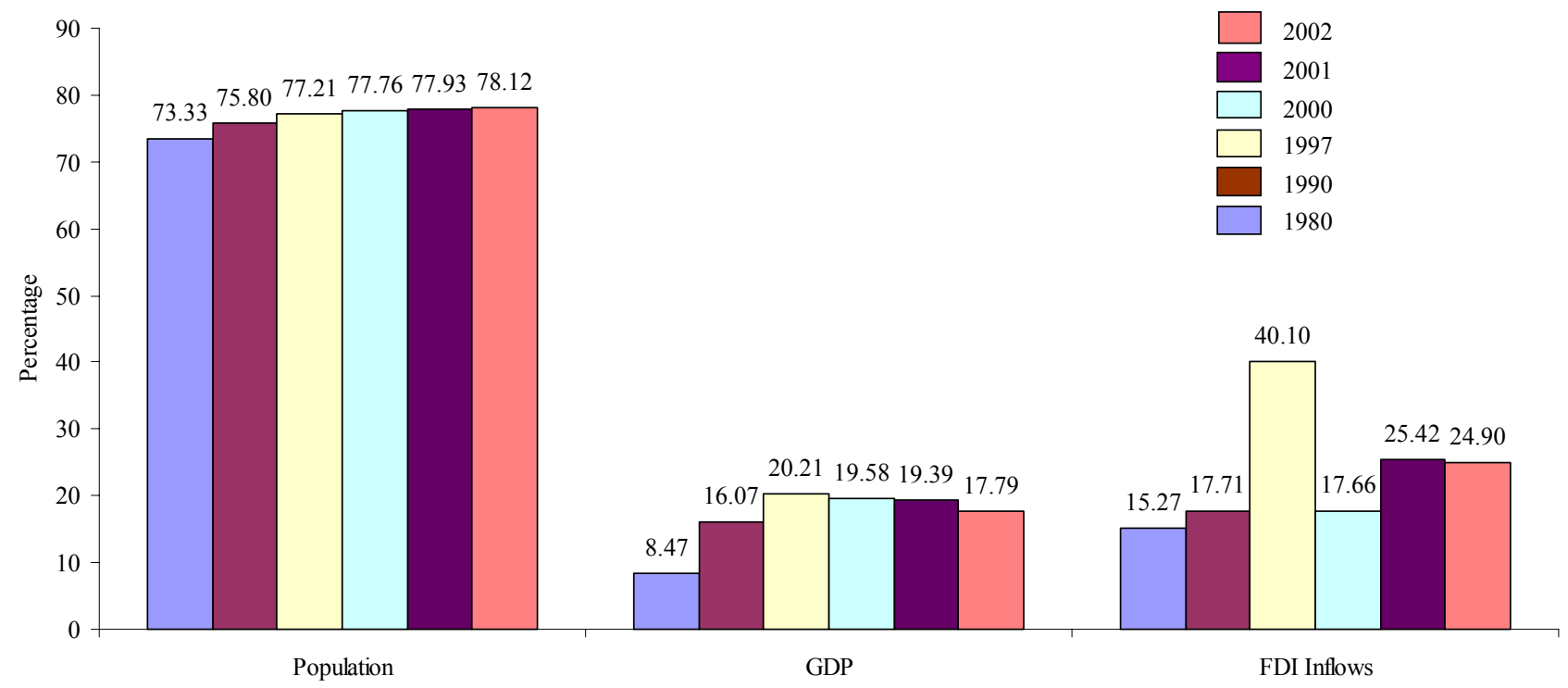


Figure 5. FDI Flows and Real GDP Growth: Low-Income, Middle-Income, and Top 10 FDI Recipients, 1990-2001
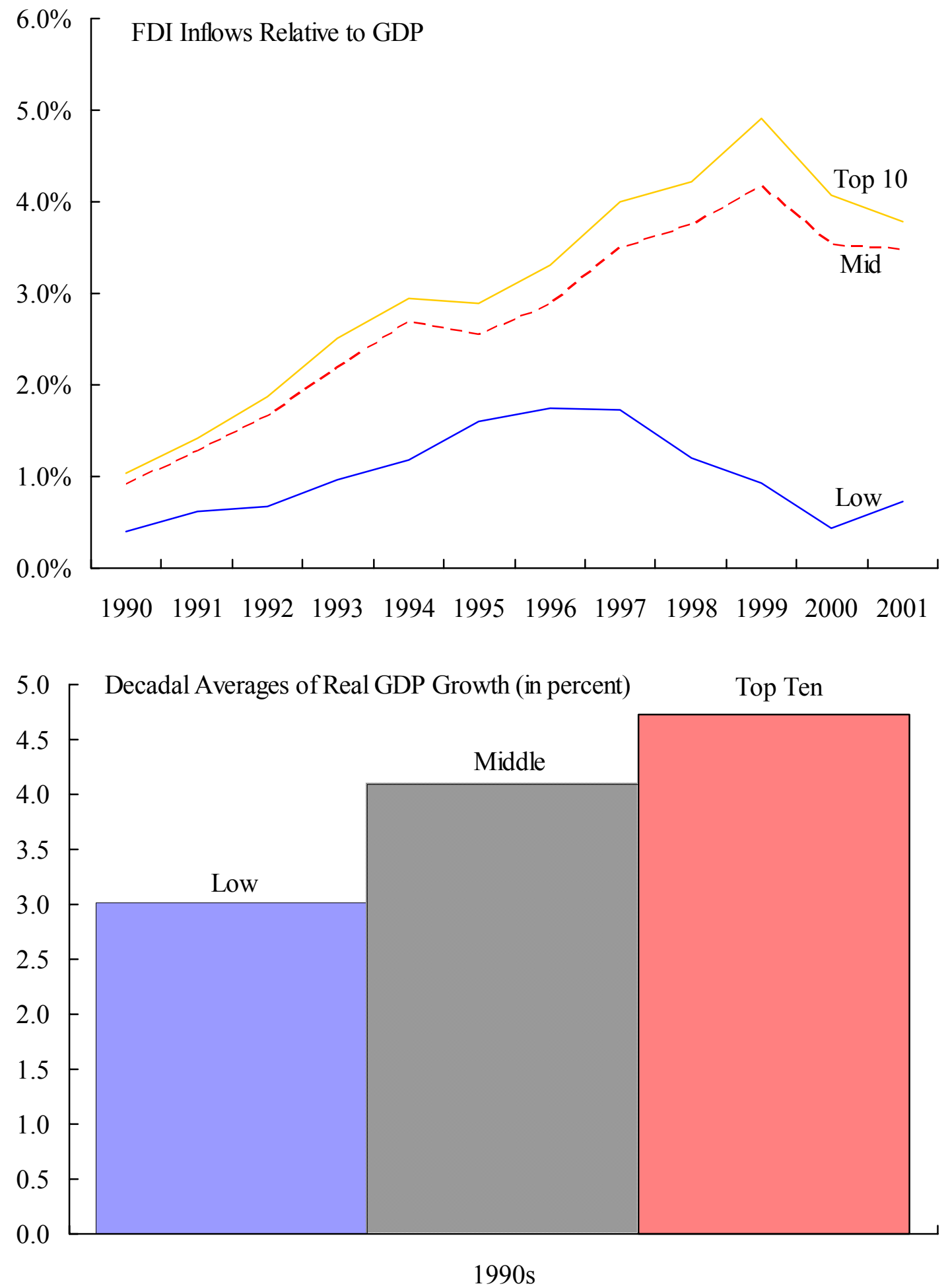
Figure 6. FDI and Growth in the 1990s
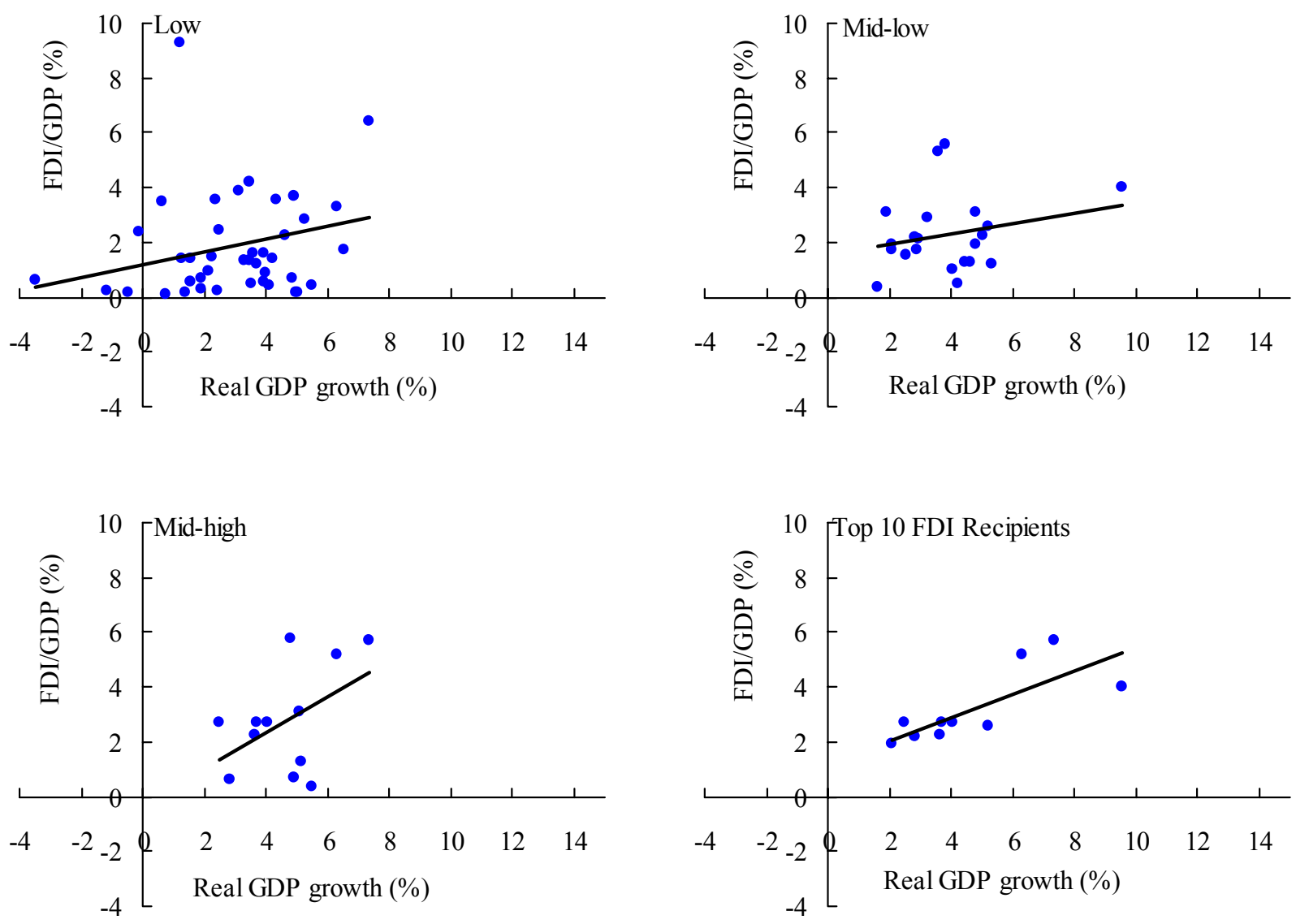